\title{
A MULTITASKING JELENSÉG HATÁSA A FELADATVÉGZÉSRE ÉS AZ IDŐBEOSZTÁSRA MÓDSZERTANI ELŐTANULMÁNY*
}

\author{
KVASZINGERNÉ PRANTNER CSILLA ${ }^{1}$ - SOLTÉSZ PÉTER ${ }^{2}$ - \\ FARAGÓ BOGLÁRKA ${ }^{3}$ - PLÉH CSABA ${ }^{4}$ - SOLTÉSZ-VÁRHELYI KLÁRA
}

${ }^{1}$ EKF Humáninformatika Tanszék; ${ }^{2}$ PPKE Általános Pszichológia Tanszék;

${ }^{3}$ EKF Pszichológia Tanszék; ${ }^{4}$ CEU Kognitív Tudományi Tanszék

e-mail:kv.csilla@gmail.com; petsol@gmail.com; faragobogi89@gmail.com; vispleh@ceu.edu; varhelyiklara@gmail.com

Beérkezett: 2015. január 10. - Elfogadva: 2015. március 27.

Háttér és célok: A modern információs és kommunikációtechnikai (IKT) eszközök alkalmazásának alapvetö jellemzöje a multitasking jellegü használat, vagyis a több információforrás párhuzamos futtatása. A tanulás kontextusában ez azt jelenti, hogy az IKT-eszközök minimális viselkedéses befektetés ellenében megkönnyítik a tanulási célunknál jutalmazóbb figyelmi folyamatok müködtetését. Vizsgálatunk célja, hogy az átlagos IKT-környezetben zajló tanulási folyamatot modellezzük laboratóriumi körülmények között, ezáltal vizsgálva a multitasking hatását a személyek feladatvégzésére.

Módszer: A vizsgálatban alkalmazott fófeladat a Flanker-teszt volt, mely az egyik leggyakrabban alkalmazott figyelmi és gátlási feladat. A fôfeladat végzését ugyanakkor idöről idöre megzavarták bizonyos (villogó vagy egyéb módon jelzö) disztraktorok, amelyek lehetövé tették, hogy a föfeladatról a vizsgálati személyek átváltsanak rájuk, és korlátlan mennyiséget ,fogyasszanak” belölük. A vizsgálatot 91 diákkal végeztük el az Eszterházy Károly Föiskoláról. Célunk a disztraktorokkal eltöltött pihenések hosszának, illetve számának föfeladatban nyújtott teljesítményre gyakorolt hatásának felmérése volt.

Eredmények: A pihenések hossza és száma, valamint a reakcióidő között nem találtunk összefüggést. Míg a pihenés hossza és a teljesítmény között erős negatív korreláció volt kimutatható, a sok megszakitás nem mutatott kapcsolatot a teljesítménnyel. Közvetlenül a pihenés után a személyek reakcióideje átlagosan javult. A több feladatot végzö személyek arányaiban jobb válaszokat adtak.

* A szerzők közötti munkamegosztás a következő volt. Kvaszinger Csilla végezte a kísérleteket. SoltészVárhelyi Klára készítette a számítógépes programot, Soltész Péter irányította az adatfeldolgozást, Faragó Boglárka tárta fel a háttérirodalmat s készítette az első szövegváltozatot. Pléh Csaba irányította a kutatást, s felügyelte a szöveg elkészítését. 
Konklúzió/következtetések: Eredményeink a pesszimista multitasking metahipotézist támasztották alá, vagyis azt találtuk, hogy a többet pihenö személyek túlbecsülik a pihenés teljesítményükre gyakorolt hatását, hiszen valójában a több pihenés rosszabb teljesítménnyel járt együtt. Viszont ha a vizsgálati személy képes korlátozni a pihenések hosszát, vagyis a disztraktív ingerek hosszú távra nem vonják el a figyelmét a fơfeladatról, ezek a rövid pihenők pozitívan befolyásolják a teljesitményt.

Kulcsszavak: IKT-eszközök, multitasking, tanulás, figyelem, önszabályozás

\section{BEVEZETÉS}

Az új technológiai környezet egyik jelentős hatása a kognitív folyamatok szabályozási, figyelmi aspektusában jelenik meg. Különösen érdekessé vált a figyelem szempontjából az új technológiák azon jellemzője, hogy állandóan változó bemenetet teremtenek, így nem tud automatikussá válni a velük végzett tevékenység, amely ezáltal állandó pszichológiai jelenlétet, vagyis állandó figyelmet igényel (Fontaine és Cheen, 2010).

Az egyik kérdés tehát, hogy képesek vagyunk-e az eszközök által prezentált információkat figyelemmel követni, s milyen módon befolyásolják az új eszközök a figyelmet. Small és Vorgan (2011) szerint ez az új technológiai környezet negatív és pozitív hatással is lehet a figyelemre nézve. Negatív hatás, hogy az állandó fokozott figyelem az embert magasabb stressznek teszi ki, ez pedig hosszú távon rontja a teljesítményünket, viszont gyakorlással képesek lehetünk megküzdeni a ránk zúduló hatalmas információmennyiséggel, és éppenséggel javulhat a figyelem. Az 1982 után született „netgeneráció” jellemzője (Oblinger és Oblinger, 2005), hogy képesek a figyelmüket azonnal az egyik feladatról a másikra irányítani, illetve képesek arra, hogy ne fordítsanak figyelmet olyan dolgokra, amelyek nem érdeklik őket. Emellett képesek gyorsan reagálni az őket érő információra, és másoktól is hasonlóan gyors reakciót várnak el, jobban tanulnak személyes felfedezés által, semmint azáltal, amit elmondanak nekik, vizuális-téri képességeik rendkívül jók (feltehetőleg a számítógépes játékok miatt képesek integrálni a virtuális világot a fizikai világgal). A netgenerációhoz tartozók preferálják a képről, hangról, videóról tanulást, szemben a szövegalapú, lépésről lépésre történő tanulással (Oblinger és Oblinger, 2005).

Egy másik szempont a figyelmi folyamat és az eszköz verzatilitásának problémája. A modern tudástechnológiai eszközöket percepciós szempontból kezdetben korlátozott modalitású eszközök jellemezték, az információk vagy vizuálisan statikus képekben, vagy hangalapon, vagy klasszikus formához sorolható mozgóképi formában érkeztek. Az új eszközök azonban a tudást több dimenzióra terjesztik ki abban az értelemben, hogy a hang, a statikus vizualitás, illetve a mozgókép egyszerre jelenhet meg az elsajátítandó anyagokban, mintegy egy csomagban. Ez a diverzitás, vélhetően a többszörös kódolás elméletének megfelelően (Paivio, 1986), mélyebb feldolgozást eredményezhet. A figyelemnek azonban egy másik aspektusa is megjelenik a bemeneti sokféleség következményeként. Az emberi figyelem jellemzője, hogy egyszerre viszonylag kevés információt fogad be és dolgoz fel. 
A figyelmi folyamatok klasszikus elméletei (például Broadbent, 1958; Treisman, 1964; Deutsch és Deutsch, 1963; Johnston és Heinz, 1978; Czigler, 2005) ugyan nem egyeznek meg abban, hogy a környezetből beérkező nagy adatmennyiséget az idegrendszer hol korlátozza a mélyebb feldolgozási szinteken, az azonban egyértelmű, hogy figyelmünk meghatározó szerepet tölt be ennek eldöntésében.

Maclin és munkatársai (2011) kutatásában a résztvevőknek egy olyan komplex videojátékot kellett játszaniuk, mely sztenderd kognitív feladatjellegủ komponenseket is tartalmaz (egy űrhajót kellett vezetni a joystick precíz használatával), illetve emellett egy másik auditoros jellegű feladatot kellett megoldaniuk (hetven különböző hang közül bizonyos magasságú hangokat kellett megszámolniuk). Ez utóbbit vagy a játék után, önmagában, vagy a játék közben kellett elvégezniük. Az eredmények szerint egyre több gyakorlással jelentős javulás mutatkozott a teljesítményben a két feladat egyszerre történő végzésekor. Vagyis a személyek képesek voltak több figyelmi forrást fordítani a hangok számolására az elsődleges feladatban javuló teljesítmény következtében (hiszen az elsődleges feladat végrehajtása ekkor már nem igényelt akkora figyelmet).

A figyelem párhuzamossága korlátozott tehát, az információk versengenek a mélyebb feldolgozásért. Különböző modalitású ingereket párhuzamosan is képesek vagyunk feldolgozni, ilyenkor a többszörös kódolás nagyobb visszaemlékezéshez vezethet (már Treisman és Davies, 1973), azonos modalitású ingeranyagok hatékony párhuzamos elsajátítását azonban gyakorlatilag csupán „cirkuszi mutatványok" keretében mnemotechnikai guruk képesek produkálni, vagy speciális környezetben trenírozott személyek (például Spelke, Hirst és Neisser, 1976; Hirst, Spelke, Reaves, Caharack és Neisser, 1980). Leghatékonyabbak abban az esetben vagyunk információelsajátításban, amikor több modalitáson azonos információhalmazt kódolunk (Paivio, 1986).

Természetesen nemcsak akaratlagos a figyelmünk, hanem az információ motivációs aspektusai is befolyásolják a feldolgozás szintjeit, így akaratlagos figyelmünk és motivációs rendszereink konfliktusba keveredhetnek (lásd már Moray, 1969). A könnyed figyelem, vagy ismertebb megfogalmazásban, a flow olyan állapotot jelöl, ahol az akaratlagos figyelem és a motivációs aspektusok integráltan müködnek. Ez azonban inkább a kivétel, mint a szabály a figyelmi helyzetekben (például Mózes, Magyaródi, Soltész, Nagy és Oláh, 2014).

Wieth és Burns (2014) kutatásukban azt vizsgálták, hogy multitasking környezetben egy külső ösztönző (ha az összes feladatot jól oldják meg, előbb vége a vizsgálatnak és hamarabb hazamehetnek a személyek) hogyan befolyásolja a problémamegoldást. A résztvevők feladata az elsődleges feladatban bizonyos problémák megoldása volt (például Anna kétszer idôsebb a fiánál. Tíz évvel ezelótt Anna háromszor idősebb volt, mint a fia. Hány évesek most?). A másodlagos feladatban egy pedált kellett nyomkodni, ha a személyek egy adott magasságú hangot hallottak. A vizsgálat után a személyeknek le kellett írniuk a legtöbb információt, amelyre a problémákból emlékeztek. Az eredmények szerint az ösztönző csak akkor volt a problémamegoldásra pozitív hatással, ha valóban egyszerre csak egyetlen feladatot kellett megoldani. Az ösztönző jelenlététől függetlenül a másodlagos feladatban mindig csökkent a teljesítmény abban az esetben, ha együttesen jelent meg az elsődleges 
feladattal. Vagyis az ösztönző nem képes felülírni a személyek figyelmi korlátait, így nem képes javítani a problémamegoldást multitasking helyzetben. Viszont az ösztönző javította a személyek emlékezetét a problémák részleteire vonatkozóan. Vagyis külső ösztönző hatására a személyek képesek voltak néhány figyelmi forrást mozgósítani a problémamegoldás érdekében, ami az emlékezet javulását eredményezte.

A feladatvégzés, amennyiben nem intrinzikus módon motivált, nem aktiválja azokat a tevékenységet értékelő idegi hálózatokat, amelyek a jutalomközponttal együttes működésben a figyelmi erőfeszítést „könnyednek”, erőfeszítés nélkülinek jelzik vissza a tudat számára. Az ACC (anterior cingulate cortex) különböző területein folyamatosan monitorozza a feladat nehézségét, az NA (nucleus accumbens) emellett a feladattal járó jutalmakat a nehézség függvényében mérlegelve (diszkontálva) követi. Az ACC múködése a feladattal járó szubjektív kellemetlenség érzésért felelős, a figyelemhez társuló erőfeszítés érzését nyújtja, így egy bizonyos viselkedés elutasításával szabályozva az erőfeszítést, amely következményeképpen a feladat fárasztónak, megterhelőnek tűnik (DeCaro és Beilock, 2010). A személy tapasztalatai, és sokszor az „akaraterővel” kapcsolatba hozott végrehajtó funkciók (Barkley, 2001) rendszereinek integráltsága dönti el, hogy képes-e figyelmét fenntartani, vagy motiválóbb, a tudatot kevésbé terhelő tevékenységbe fog.

Az új IKT-eszközök pontosan ezt a problémát vetik fel. Valóban párhuzamos-e a feladatvégzés, vagy aktívan kitérünk más feladatokra, éppen a megnyugvás és pihenés érdekében? A könyvtárak, elszeparált tanulózugok egyfajta védett környezetet teremtenek a tanulni vágyónak, nem beszélve a könyvtárak szociális aspektusairól, amikor a többi tanuló erőfeszítései transzparensek a befogadó számára, amely szociálisan megerősíti tevékenységében. Ezzel szemben az IKT-eszközök „magányos” használatúaknak tekinthetőek több szempontból: egyrészről túl ingergazdagok ahhoz, hogy felnézzünk belőlük, figyelmünket a tágabb külvilágra irányítva, másrészről nagy részük helyhez kötött használatra korlátozódik (bár kétségtelenül egyre kisebb mértékben). Természetesen a megvalósuló szociális támogatás is lehet negatívum a tanulás szempontjából, amennyiben a szociális ingerek kommunikációs aspektusai erősödnek fel. Az elvonulva végzett elsajátítás egyesek számára a külső ingerek korlátozásának hatékony eszköze, hiszen sokak számára a vonzó ingerek eltávolítása célravezető számukra. Az ilyen viselkedéses önszabályozás azonban sikertelen lehet, amennyiben a modern eszközök is jelen vannak. Jackson (2008) szerint ez már a televízióra is igaz volt. A tévé a legerősebb figyelem elvonására alkalmas találmány (gondoljunk csak a látszólag elmélyülten játszó gyerekre, aki időről időre a bekapcsolt tévére pillant, megszakítja játékát, nem képes elvonatkoztatni a „bűvös doboztól”).

Ezeket a technológiákat ugyanakkor nem szabad pusztán eszközökként kezelni, mint ahogyan a könyv sem a papír minőségén keresztül ragad meg, hanem a közvetített információkon keresztül. Ebben az értelemben, kiváltképpen az internethez való kapcsolódás esetén egy információ szempontból végtelen disztraktorról vagy értéksemleges szemszögből végtelen figyelmi mezőrőll beszélhetünk. Az eszköz lehetőséget nyújt arra, hogy minimális viselkedéses befektetés ellenében az esetleges tanulási célunknál jutalmazóbb figyelmi folyamatokat múködtethessünk 
belső jutalmazó-ösztönző rendszereinknek engedelmeskedve. Egy kutatás résztvevői arról számoltak be, hogy technológia nélkül nem tudják elképzelni az életüket, hiszen élvezetes tevékenységformákat nyújt számukra, valamint a multitaskingot életük mindennapi, rutinszerű tevékenységeként írták le. A vizsgálat szerint a személyek olvasás közben átlagosan három vagy négy más médiaformát használnak egy időben. Az öt legkedveltebb tevékenység olvasás közben; számítógéphasználat, zenehallgatás, sms-ezés, közösségi oldalak használata, tévénézés (Tran, Carrillo és Subrahmanyam, 2013).

Voorveld és van der Goot (2013) a multitasking életkori különbségeit vizsgálva arra a megállapításra jutott, hogy a multitasking minden életkori csoportnál megjelenik naponta több mint egy óra intervallumban. A legtöbb időt a 13-16 évesek töltik multitaskinggal, őket követik az 50-65 évesek, végül a 17-24 évesek. Természetesen az egy időben használt média formájában van eltérés az életkori csoportok között; a fiataloknál inkább a zenehallgatás és különböző online aktivitások, az idősebbeknél a rádióhallgatás és újság- vagy e-mail olvasás együttes megjelenése számottevő.

A multitasking mint működésmód egyrészről pszichológiai folyamatokat jelöl (például Sanbonmatsu, Strayer, Medeiros-Ward és Watson, 2013). A korábban leírtak miatt valós, ténylegesen egyidejủ multitasking csupán nagyon korlátozott módon zajlik az emberi idegrendszeren keresztül. A szakirodalom valós párhuzamos feldolgozás helyett inkább az automatikus implicit készségeken (ami az új információ elsajátítása után csak intenzív gyakorlás révén jelentkezik) (Blais, 2010), illetve a prospektív memória feladatmenedzsmentjén keresztül képzeli el a multitasking működés lehetőségeit (például Monsell, 2003; Sanjram és Khan, 2011). A prospektív memória olyan memóriafolyamatokat jelöl, amelyek során az elvégzendő folyamatokra emlékezünk, és megfelelő cue-k hatására az aktuális tevékenységünket felfüggesztve az elvégzendő feladat felé fordulhatunk (Eysenck, 2010). Tehát humán értelemben multitasking helyett inkább egyetlen szálon futó meg-megszakított figyelmi folyamatról beszélhetünk. Bizonyos prioritások szerint felosztjuk és rangsoroljuk a feladatokat, és ebből csak akkor tudunk kilépni, amikor magasan automatizált (implicit) tudásunkat aktiválva egy-egy folyamatot bizonyos mértékben, bizonyos ideig figyelmünkkel elengedhetünk. Az egyik feladatról másikra való váltás ugyanakkor költségekkel is járhat; hiszen ha megosztjuk a figyelmünket több feladat között, nem tudjuk az információkat hatékonyan tárolni, vagyis ez Jackson (2008) szerint a hosszú távú memóriába történő raktározást negatívan befolyásolhatja.

Pashler, Kang és Ip (2013) kutatásukban a multitasking teljesítményre gyakorolt hatását vizsgálták. A résztvevőknek egy történelmi szöveget kellett olvasniuk, vagy hallgatniuk, és közben rövid szöveges üzeneteket váltaniuk egy másik személlyel. A kutatás eredményei szerint az utólagos szövegértési feladatban a teljesítményük csak akkor csökkent, ha auditív formában jelent meg a szöveg, és a résztvevőknek nem volt lehetőségük megállítani azt arra az időre, amíg válaszolnak a kapott üzenetre. Ez utóbbi helyzet a valós tantermi helyzetet is modellezheti, mely során hang alapon érkezik az információ a tanártól, és nincs lehetőség megszakítani az előadást az üzenetváltás idejére. Hasonló módon, ha például 
egyetemi óra alatt nyitott laptopok mellett a diákok wifizhetnek, akkor sokkal kevesebbet tudnak arról, hogy mi volt az órán. (Ez még abból az időből származó eredmény, amikor még nem voltak okostelefonok s átfogó wifizés!) A hírek alatt futó szalaghíreket olvasó, figyelmüket megosztó személyek kevesebbet tudnak arról, hogy mi volt az eredeti, képernyőn elhangzott vagy látott hír (Greenfield, 2009).

A multitasking a számítógépekben korábban hasonlóképpen (inkább szeriálisan át-átadva a vezérlést az egyetlen processzormag felett) működött (Hwang, 2003), ma a többprocesszoros rendszerek világában ez egyre kevésbé igaz, azonban az emberi észlelés szempontjából a korai szakaszok a klasszikus elképzelések szerint (Broadbent, 1958; összefoglalásukra Czigler, 2005) gyakorlatilag folyamatos párhuzamos működésnek tekinthetőek. Ennek kutatásunk szempontjából releváns vetülete, hogy a mai IKT-használat alapeleme a multitasking jellegű használat, vagyis több párhuzamos információforrás futtatása, esetleg szinte azonnali indítása. Tehát a modern eszközök használata közben azonnal megszakíthatjuk tevékenységünket, és egy másik tevékenységre válthatunk, anélkül hogy akár helyzetünket változtatnánk, akár tekintetünket máshova függesztenénk (Judd, 2013). Mindent megpróbálunk úgy kezelni, mintha az észlelés korai, párhuzamos szakaszaihoz tartozna.

Joggal vetődik fel, hogy a figyelmi folyamatok és a modern IKT-eszközök között kölcsönhatás alakul ki (Adler és Benbunan-Fich, 2012)*. Kérdés, hogyan befolyásolja mindez a személyek teljesítményét? Az eredmények nem támasztják alá egyértelműen a multitasking teljesítményre gyakorolt feltételezhető negatív hatását. Rosen, Lim, Carrier és Cheever (2011) osztálytermi körülmények között vizsgálták a multitasking hatását a felidézési teljesítményre. A személyek egy tanórán vettek részt, s ennek során szöveges üzeneteket kellett váltaniuk más személyekkel (a résztvevők különböztek abban, mennyi üzenetváltás történt; kevés, közepes mennyiségű vagy sok). Feltételezésük szerint, minél több üzenetváltás történik, annál rosszabb lesz az órán elhangzott információkra vonatkozó felidézési teljesítmény. Ez a hatás azonban csak minimálisan jelent meg; csak a sok üzenetet váltó csoport különbözött azoktól, akiknél nincs vagy alacsony számú üzenetváltás történt, és itt is csak 10,6\%-os romlást eredményezett a memóriában. Azok a személyek, akik hosszabb, több szóból álló üzeneteket küldtek, rosszabbul teljesítettek, de ezt a hatást is csökkentette az eltelt idő a kapott üzenet és a válasz között. Vagyis azok a személyek, akik 4-5 percnél többet vártak, hogy válaszoljanak az üzenetre, jobban teljesítettek, mint akik azonnal válaszoltak, hiszen az előbbiek megvárták, míg olyan részhez ér az előadás, amelyről feltételezték, hogy a vizsga szempontjából kevésbé releváns információt közöl.

Egy másik vizsgálatban a multitasking az elvárásokkal teljesen ellentétes, pozitív hatást gyakorolt a személyek teljesítményére. A vizsgálati személyeknek olyan feltáró jellegű cikkeket kellett olvasniuk, amelyekkel tanulmányaik során is találkozhatnak, közben pedig online felületen kommunikációt kellett folytatniuk. Az eredmények szerint a másodlagos kommunikációs helyzet bevezetése jótékony ha-

" http://www.sciencedirect.com/science/article/pii/S1071581911001431 - aff2 
tással volt a szövegértési teljesítményre, de csak könnyű szövegek esetén (Tran, Carrillo és Subrahmanyam, 2013). Fante, Jacobi és Sexton (2013) hasonló eredményre jutottak (bár náluk a multitasking nem eredményezett teljesítményjavulást, de romlást sem). A jelenséget a kutatók a hallgatók azonnali üzenetváltást lehetővé tevő eszközökkel való előzetes tapasztalatával magyarázták, amely lehetővé teszi számukra, hogy negatív hatások nélkül váltsanak az olvasási feladatról a csevegésre.

Nijboer, Taatgen, Brands, Borst és van Rijn (2013) a multitasking helyzethez való viselkedéses adaptáció lehetőségét vetették fel, mellyel magyarázható lehet a teljesítményromlás hiánya ilyen helyzetekben. A résztvevők által megoldandó elsődleges feladat könnyü és nehéz kivonás volt. A másodlagos feladat kétféle lehetett; egy mozgásos jellegű (követés: egy körben kellett tartani a mozgó pontot) és egy számolási feladat (fülhallgatóba adott hangok számolása). A résztvevők először megoldották az összes lehetséges kombinációt a feladatokból, majd ők választhattak a kombinációk közül annak tudatában, hogy az elsődleges kivonási feladat nehéz vagy könnyű (az instrukció az volt, hogy mindkét feladatban próbáljanak meg a lehető legjobban teljesíteni). Az eredmények szerint valóban a legnagyobb interferenciát okozó kombináció vezetett a legrosszabb teljesítményhez (vagyis a nehéz kivonás és a hangok számolása), majd ezt követte a nehéz kivonás és a követés. A legkisebb interferencia a könnyủ kivonás és a követés, majd a könnyű kivonás és a számolási feladat együttes végzésénél jelent meg. A kutatók feltételezése szerint az első rész után (mikor bemutattak nekik minden kombinációt) a személyek adaptálódnak a multitasking interferenciához, vagyis a könnyủ feladatokhoz a számolást, a nehezekhez a követést fogják választani. Viszont csak részben adaptálódtak; a könnyü feladatokhoz valóban a számolást választották, a nehezeknél viszont sokkal kisebb preferencia jelent meg a követés iránt. Vagyis a legtöbb ember nem eléggé adaptálta a választásait a multitasking interferencia minimalizálása érdekében. A vizsgálat továbbgondolása során a kutatók minimalizálták annak az esélyét, hogy a személyek minden esetben ugyanazt a másodlagos feladatot válasszák, és ennek hatására már egyre növekvő számban jelent meg a választási adaptáció, viszont időbe telt, míg a választások teljesen adaptálódtak volna, a résztvevők nem azonnal ismerték fel azokat a kombinációkat, amelyek minimalizálják az interferenciát.

\section{VIZSGÁLATI CÉLOK}

Kutatásunkban a valós élet multasking helyzeteit próbáltuk laboratóriumban modellálni. Az egyszerű, könnyen kivitelezhető módszer kialakításán túl vizsgálatunk célja annak mérése volt, hogy kísérleti személyek multitasking környezetben, illetve a multitasking helyzet különböző variálásával a főfeladatban hogyan teljesítenek, miközben különböző elterelők (disztraktorok) jelennek meg, illetve a vonzó elterelések folyamatosan elérhetőek a feladatvégzés közben.

Olyan helyzetet próbál a kísérlet modellálni, amikor egy személy közepes időnyomás alatt dolgozik számítógépen, és megengedheti magának, hogy szüneteket 
tartson a végzett feladatban (vagyis egy általános IKT-környezetben végzett tanulási helyzetet). A kísérleti helyzetben a főfeladat a könnyű mérhetőség érdekében a jól bevált Flanker-teszt (oldalazó próba). A disztraktorok pedig olyan feladatok, amelyeket multitasking környezetben gyakran előkerülnek mint „pihenésre alkalmas" elterelések: érdekes videók, rövid képregényrészletek, vicces vagy érdekes képek, a mindennapi élethez kapcsolódó rövid cikkek stb. Arra voltunk kíváncsiak, hogy az elsődleges feladat ily módon való megszakítása hogyan befolyásolja a teljesítményt. Illetve azt is vizsgáljuk, hogy a különböző személyek, aszerint hogy milyen „multitasking” stratégiát alkalmaznak, milyen hatékonyan végzik a feladatot.

\section{Részletes hipotézisek}

\section{A pihenések hossza}

1. Feltételezzük, hogy pozitív korreláció várható az összpihenés hossza (\%-osan megadva) és az átlagos reakcióidő között, tehát a pihenés javítja a reakcióidőt.

2. Feltételezzük, hogy az összpihenés hossza (\%-osan megadva) és a teljesítmény (= jó leütések száma) között nincsen releváns összefüggés.

Ez utóbbi hipotézist pihenés-paradoxonnak neveztük, feltételezésünk szerint ugyanis a személyek úgy pihennek, hogy végeredményben a reakcióidőjavulás és a pihenés ideje kompenzálják egymást, a pihenés csupán egy erőforrás-optimalizálás.

\section{A pihenések száma}

3. Feltételezzük, hogy pozitív összefüggés várható a pihenések száma (db) és az átlagos reakcióidő között.

4. A rövid, de sok kis pihenő jobban javítja a teljesítményt, mert a pihenés hatása rövid, de a pihenés gyorsan kifejti hatását.

5. Feltételezzük, hogy a pihenések száma $(\mathrm{db})$ és a teljesítmény (=jó leütések száma) között nincsen releváns összefüggés.

A korábban említett kompenzáló hatást a sok rövid idejű pihenés adja.

6. Megfogalmaztunk egy pesszimistább metahipotézist a hatékonysággal és a váltás költségével kapcsolatosan. Feltételezhetjük, hogy az IKT-használattal kapcsolatban létezik egy multitasking-paradoxon, amelynek két eleme van:

- A számítógép megkönnyíti a feladatok közötti váltást, amivel a váltás költségét csökkenti.

- A váltás költsége csökken, de összességében a váltás miatti költségek a hatékonyságot csökkentik (túlkompenzáció).

Tehát a váltás megkönnyítése több multitaskinggal jár, ami végeredményben teljesítménycsökkenéshez vezet, vagyis elhitetjük magunkkal, hogy a pihenés majd jót tesz. Ez igaz, azonban a pihenés teljesítménynövelő hatását a teljes feladatvégzésre eltúlozzuk, a pihenés „veszteségeit” pedig alábecsüljük. 


\section{MÓDSZEREK}

\section{Általános elrendezés}

Munkafelületként egy olyan környezetet fejlesztettünk ki, amely egy komplexebb multitasking környezet analógiájaként működik. Mint a megszokott Windows „taskbar”-on itt is több „alkalmazás” fut párhuzamosan, melyek között a váltás egyetlen kattintásnyira van. Egy oldalon található a végzendő feladat, amely egy Flanker-tesztet tartalmaz (1. ábra). Ez az elsőként Eriksen és Schultz (1979) által kialakított feladat a Stroop-próba mellett a legtöbbet alkalmazott figyelmi és gátlási feladat. Lényege, hogy a képernyőn megjelenő nyilak mintázatát kell figyelni és követni.

Ugyanakkor az általunk kialakított változatban több indikátor jelzi időközönként, hogy valamilyen elérhető pihenést szolgáló információ (disztraktor) van. Egyrészről a felugró buborékokat szimuláló, másrészt a „taskbar”-on való villogtatást szimuláló disztraktorok, melyek az IKT-használatban gyakori jelzések. Ha a

A következö tesztben arra kérünk, hogy azt a nyilat nyomd meg a billentyüzeten, amelyik irányba a képernyőn megjelenő nyilak közül a KÖZÉPSÖ mutat. A többi nyilat próbáld figyelmen kívül hagyni. A nyilak a képernyön a következö hét elrendezésben jelenhetnek meg, az alábbi ábrán bejelöltük, melyik nyilat tekintsd középsőnek. Próbálj meg minél gyorsabban dolgozni, de törekedj a pontosságra is!
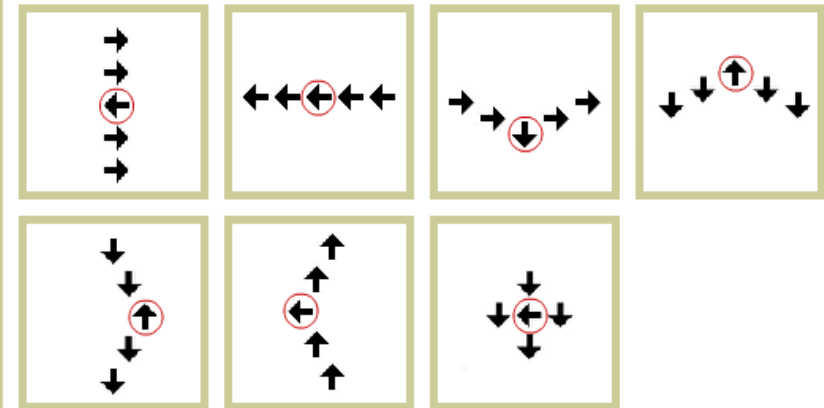

\section{MEHET}

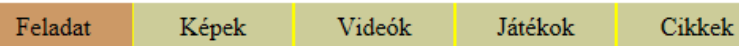

1. ábra. A Flanker-teszt nyitóképernyője 
személy igennel válaszol az ikonra, vagy a disztraktort jelző fülre kattintva a feladat leáll, és átvált az adott disztraktorra, amely az alkalmazás egy külön fülén érhető el (2. ábra).

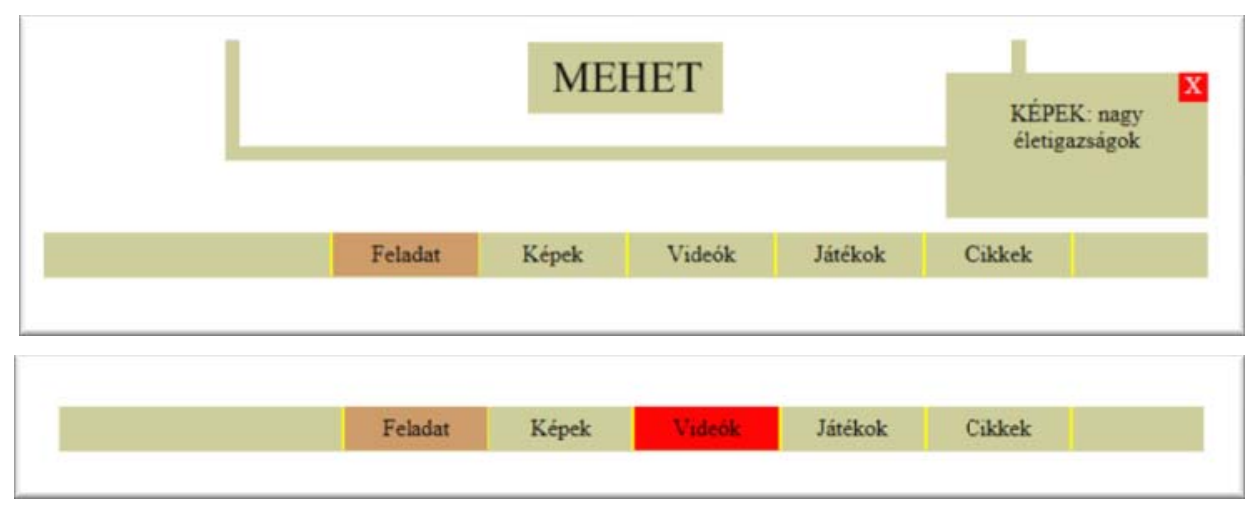

2. ábra. Multitasking felület „taskbar” része,

„felugró” és „villogó” disztraktorfunkció bemutatása

A disztraktorral való foglalkozás végén a vizsgálati személynek lehetősége van további disztraktorok megtekintésére (3. ábra). A disztraktorokból relatíve „korlátlan” mennyiség áll rendelkezésre, így ezekből új érkezését nem jelöli kis ikon, hanem az adott fülre kattintva a feladatvégzés leáll, és a disztraktorból korlátlan egység „fogyasztására” nyílik alkalom.

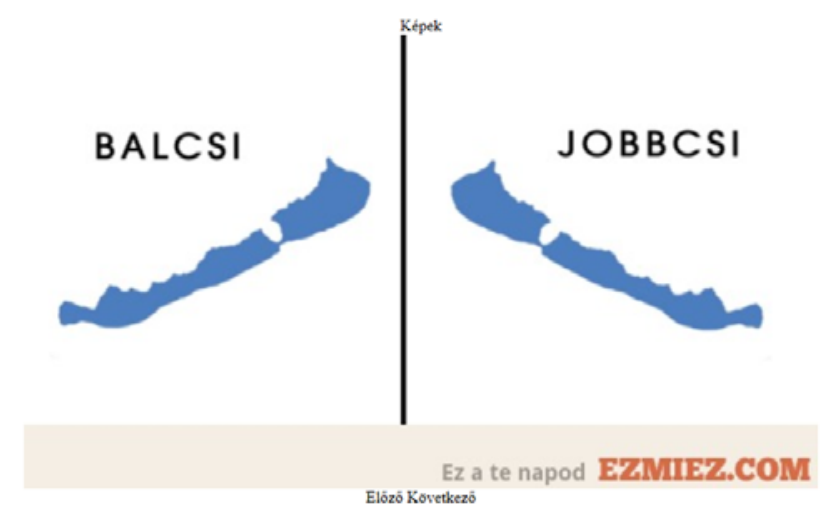




\section{A vizsgálat menete}

A vizsgálati személy a vizsgálati helyiségben egy előre elkészített szoftveren (amely böngészőben fut) végzi a feladatot. A vizsgálati személynek bemutatjuk a főfeladatot, majd a munkafelületet, a disztraktorokra váltás lehetőségét, az új disztraktorok megjelenését jelző ikonokat és azok működését. Felolvassuk az instrukciót és elkezdjük a vizsgálatot, amely 25 percig tart. A vizsgálat végén tájékoztatjuk a személyt a vizsgálat tartalmáról és értelméről.

Instrukció: Arra kérjük, hogy gondoljon erre az alkalomra úgy, mint egy helyzetre, amelyben jó lenne az adott feladatot befejezni, hogy pl. holnap már ne kelljen vele foglalkozni. A feladat folyamatos munkavégzéssel $k b .20$ perc alatt teljesíthetö, de a vizsgálat mindenképpen tovább fog tartani. Mivel a feladat monoton, a pontosság pedig lényeges ebben a feladatban, a leghatékonyabb munka érdekében lehetöséget adunk arra, hogy pihentetó információkkal foglalkozzon a feladatvégzés közben (itt bemutatjuk a disztraktorokat). Ezekból az információkból korlátlan mennyiség áll rendelkezésére. A rendelkezésére álló információkat bármikor annak fülére kattintva is elérheti, a feladat fülére kattintva pedig folytathatja a feladatot. A vizsgálat az összes nyál (Flanker-teszt, ezt külön elmagyarázzuk) megválaszolásával, de a kezdéstől számított legalább 30 perc múlva ér véget, az idöt Ön belátása szerint osztja fel munkára és pihenésre. Hogy a feladat nagy részével mindenképpen végezni tudjon, arra kérjük, hogy az ideje legalább 50\%-át a feladattal töltse, viszont az idó legalább negyedében pihenjen, hogy hatékonyabban menjen a munkavégzés. A pihenési időt annak függvényében szabályozzák, hogy a lehető leghatékonyabban végezhessék a munkát. Emiatt is kérjük meg még arra, hogy amennyiben egyszer a föfeladattal kezd foglalkozni, azt legalább 1,5-2 percig csinálja egyhuzamban. Kérjük, igyekezzenek gyorsan és pontosan dolgozni, a megadott idői korláton belül minél több feladatot megoldani.

\section{Mutatók}

\section{Vizsgálati mutatók}

A feladatvégzés során mértük a kapott feladatok darabszámát, azaz mennyi nyilat kellett leütni, a hibás leütéseket, a kihagyásokat (több mint 2s-ig nem történt leütés), az epochok számát (egyhuzamban történt feladatvégzések, amelyeket pihenéssel szakított meg), a tényleges feladattal töltött időt, valamint a reakcióidőt.

A feladatvégzés esetében adottak voltak bizonyos paraméterek: a teljes feladat ideje (valójában 25 perc), leütések után kb. 1,5 másodpercre (1 és 2 sec közötti idő véletlenszerűen) kapta a vizsgálati személy a következő feladatot.

Az így nyert adatokból számított értékek voltak:

- a jó leütések száma és aránya;

- átlagos reakcióidő;

- átlagosan mennyit javult a reakcióidő a pihenések hatására;

- pihenések utáni 14 első leütés átlagos reakcióideje;

- az első feladatrész első 50 leütésének átlagos reakcióideje;

- utolsó feladatrész utolsó 50 leütésének átlagos reakcióideje. 


\section{Személyek}

Összesen 91 az Eszterházy Károly Főiskolára járó diák végezte el a feladatot. Beleegyező nyilatkozatot töltöttek ki, s a vizsgálat egészét a SE Pszichiátriai és Pszichoterápiás Klinikájának etikai bizottsága engedélyezte. 20 mérés esetében a személy nem tartotta be az utasításokat, ezeket az adatokat nem vettük figyelembe, vagyis összesen 71 mérést használtunk fel. Az adattisztítás során a kizárások oka valamely mutatóban való outlier tagság volt, amely mögött az instrukciók be nem tartása volt tetten érhető. Ezek a következőek voltak:

- 2 személy - 2 epochot csinált, nem pihent;

- 1 személy - 195 hibát ejtett, ami véletlenszerủ nyomogatásra utal;

- 1 személy - túl sok kihagyást vétett, nem figyelt a feladatra $(>70)$;

- 8 személy - nagyon kevés leütést végzett a Flanker-teszten $(<200)$;

- 8 személy - a főfeladattal a teljes idő 90\%-ánál többet vagy 30\%-ánál kevesebbet foglalkozott, vagyis nem tartotta be az instrukciót.

\section{EREDMÉNYEK}

Eredményeink alapján az első hipotézist megalapozatlannak találtuk, a pihenések hossza és a reakcióidő között nem volt összefüggés $(r=-0,093 ; p=0,44)$. Tehát valószínủ, hogy maga a pihenés relatív ideje független az átlagos reakcióidőtől, a pihenés nem javítja a feladatvégzés hatékonyságát.

A pihenés hosszának és a teljesítménynek az összefüggése, vagyis a pihenésparadoxon szintén nem igazolódott be, a két változó között szignifikáns, nagy erősségű negatív korrelációs összefüggés mutatható ki $\left(r=-0,678^{* * *} ; p<0,001\right)$, amely egyszerủen az időgazdálkodás félreértéséből (amely az instrukció hatása is lehet) fakad. A pihenés egyértelműen elveszi az időt a feladattól, az idő pihenésre és munkára való felosztása kényelmi szempont szerint alakul.

A pihenések számának (db) és a reakcióidőnek az összefüggésénél azt vártuk, hogy a reakcióidő javul a rövid pihenők hatására, a valóságban azonban a pihenés nem volt hatással a feladatvégzésre $(r=-0,190 ; p=0,113)$.

A pihenések száma $(\mathrm{db})$ és a teljesítmény összefüggése sem hipotéziseink mentén alakult, hiszen nem vethetünk el egy gyenge negatív összefüggést a pihenések száma és a teljesítmény (= jó leütések száma) között $(r=-0,197 ; p=0,100)$. Tehát 3. hipotézisünk valószínűleg téves. Érdekes azonban, hogy míg a pihenéssel töltött idő erős kapcsolatot mutat a teljesítménnyel, addig a sok megszakítás nem.

A hipotézisek elvetése ellenére, közvetlenül a pihenések után mért reakcióidő javult átlagosan, noha az átlagos javulás $(25,6 \mathrm{~ms})$ alig érte el a szignifikanciaszintet $(p=0,046)$. Ezt személyekre a 4 . ábra foglalja össze. 


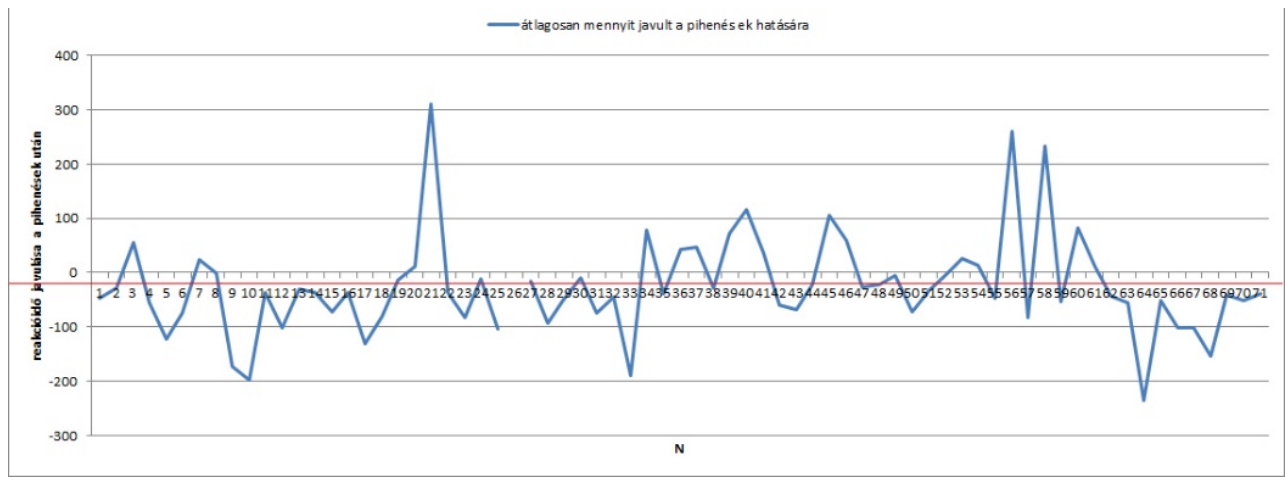

4. ábra. Személyek reakcióidő javulása a pihenések hatására

\section{A pesszimista metahipotézis további alátámasztása}

Eredményeink a pesszimista multitasking metahipotézist támasztják alá. A sokat pihenő személyek túlbecsülik a pihenés hatását, és teljesítményük rosszabb, mint kevesebbet pihenő társaiké. Hiába pihennek többet, a pihenés hatását nem mérik fel (tulajdonképpen úgy tűnik, hogy nincs, vagy minimális), és azt gondolják, hogy teljesítményüket a pihenés javítani fogja, amivel a pihenésre fordított időt visszanyerhetik. Ez azonban tévedésnek bizonyul.

Ezen pesszimista metahipotézis visszaigazolására további post-hoc elemzéseket végeztünk. Azt találtuk, hogy a több feladatot végzők arányaiban is jobb válaszokat adtak (Próbák száma vs. Jó válaszok aránya: 0,509***). Emellett azt találtuk, hogy a vizsgálati személyek próbáltak időgazdálkodást folytatni. Minél többször pihentek, annál rövidebb időkre osztották a pihenésüket (Epochok száma vs. Pihenési idő / epoch: $\left.-0,439^{* * *}\right)$. A kitartó és sokat teljesítő vizsgálati személyek emellett kevésbé variábilisan reagáltak a vizsgálati helyzetre (Próbák száma vs. RI szórása: $-0,242^{*}$ ). Minél több munkát végzett valaki, annál rövidebbeket pihent (Próbák száma vs. Pihenési idő / epoch: $\left.-0,529^{* * *}\right)$, viszont minél rövidebbeket pihent annál lassabban reagált átlagosan (Átlag RI vs. Pihenési idő / epoch: -0,335**), ugyanakkor a pihenések száma nem befolyásolta a reakcióidőt. Egyszerủ időgazdálkodási összefüggés, amely megerősíti a korábban elhangzottakat, hogy a tényleges feladattal töltött idő negatív összefüggésben ált a pihenések hosszával (Tényleges feladattal töltött idő vs. Pihenési idő / epoch: $\left.-0,595^{* *}\right)$. A pihenés enyhe hatása mutatkozott abban, hogy a megszakítások számának növekedése tendenciaszerű összefüggést mutatott az első 50 és utolsó 50 művelet reakcióidő-különbségével $(r=0,288)$.

\section{Konklúzió}

A vizsgálat során tehát pesszimista metahipotézisünk igazolódott be: akik többet pihennek, kevesebbet dolgoznak. Ez az eredmény azonban lehet félrevezető is. 
Amennyiben nem egy valós kognitív eltolódás áll az eredmények hátterében, elképzelhető, hogy a különbségeket a feladat szubjektív értelmezése, vagy egyszerűen az időérzék egyéni varianciájából fakadó többet pihenés okozta.

Eredményeink szerint a hibákkal, kihagyásokkal, általános reakcióidővel nem mutatott összefüggést a pihenések száma, ami azonban megfontolandó a rövid pihenés(ek) pozitívan befolyásolják a folyamatot. Természetesen nem feltétlenül minden feladat kíván meg hasonló figyelmet, ugyanakkor minden feladatra igaz, hogy egyszerű figyelmi mechanizmusok teremtik meg a feladatvégzés alapjait.

A pihenések mennyisége ugyanakkor nem mutat összefüggést a teljesítménynyel, tehát a rövid pihenések hatékonyak lehetnek, amennyiben a pihenő személy korlátozni tudja a pihenés hosszát. Összességében csak az határozza meg a teljesítményt a feladatban, hogy a disztraktív ingerek mennyire képesek megragadni a figyelmünket hosszú távra. Amennyiben reziliens módon a disztrakció után visszatérünk a feladatvégzéshez, a rendelkezésre álló idő nem rövidül le. Amennyiben azzal áltatja magát a feladatvégző személy, hogy a pihenés hatására teljesítménye javulni fog, akkor könnyen lehet, hogy a pihenés hatását eltúlozza, a pihenésre szánt időt pedig alábecsüli. Ilyen értelemben a leginkább hasznos stratégia a rövid, de számosabb pihenés, a kevés, de hosszúval szemben.

\section{MEGVITATÁS ÉS KITEKINTÉS}

A kidolgozott multitasking feladat alkalmas egy bizonyos feladat disztraktorok közé beágyazott mérésére. Ez a paradigma arra nyújt lehetőséget, hogy életszerű körülmények között vizsgáljuk a feladatvégzést, a motiváció, fáradtság, figyelmi és végrehajtó funkciók együttes hatását kell mérnie. Értelmetlen steril feladatok mérésével vizsgálódni, különösen olyan megterhelő feladatkörök tekintetében, mint a vizsgára készülés, hiszen alapvetően, nem a figyelmi folyamatok, hanem az önregulációs folyamatok azok, amelyek a kitartást meghatározzák, ilyen értelemben, pedig azt kell modellezve mérnünk, hogy egy modern tanulóeszköz mennyiben segíti vagy korlátozza ezeket az önszabályozási tendenciákat, amellett hogy nyilvánvaló előnyökkel kecsegtet.

\section{IRODALOM}

Adler, R. F., \& Benbunan-Fich, R. (2012). Juggling on a high wire: Multitasking effects on performance. International Journal of Human-Computer Studies, 70(2), February 2012, 156-168.

Barkley, R. A. (2001). The Executive Functions and Self-Regulation: An Evolutionary Neuropsychological Perspective. Neuropsychology Review, March 2001, 11(1), 1-29.

Blais, C. (2010). Implicit versus deliberate control and its implications for awareness. In B. Bruya (Ed.), Effortless attention: A new perspective in the cognitive science of attention and action (pp. 141-157). Cambridge, MA: MIT Press.

Broadbent, D. E. (1958). Perception and communication. Oxford: Pergamon. 
Czigler I. (2005). A figyelem pszichológiája. Budapest: Akadémiai Kiadó.

DeCaro, M. S., \& Beilock, S. L. (2010). The benefits and perils of attentional control. In B. Bruya (Ed.), Effortless Attention: A new perspective in the cognitive science of attention and action (pp. 51-73). Cambridge, MA: MIT Press.

Deutsch, J. A., \& Deutsch, D. (1963). Attention: Some theoretical considerations. Psychological Review, 70, 80-90.

Eriksen, C. W., \& Schultz, D. W. (1979). Information processing in visual search: A continuous flow conception and experimental results. Percept Psychophys., 25, 249-263.

Eysenck, M. W. (2010). Prospektív emlékezet. In A. Baddeley, M. W. Eysenck és M. C. Anderson (szerk.), Emlékezet (pp. 508). Budapest: Akadémiai Kiadó.

Fante, R., Jacobi, L. L., \& Sexton, V. D. (2013). The Effects of Instant Messaging and Task Difficulty on Reading Comprehension. North American Journal of Psychology, 15(2), 287 298.

Fontaine, G., \& Cheen, G. (2010). Presence in Teleland. In K. E. Rudestam, \& J. Schoenholtz-Read (Eds.), Handbook of online learning (pp. 30-56). London: SAGE Publications, Inc.

Greenfield, P. (2009). Technology and informal education: What is taught, what is learned. Science, 323, 68-71.

Hirst, W., Spelke, E. S., Reaves, C. C., Caharack, G., \& Neisser, U. (1980). Dividing attention without alternation or automaticity. Journal of Experimental Psychology: General, 109, 98-117.

Hwang, K. (2003). Advanced Computer Architecture. New York: McGraw-Hill Education.

Jackson, M. (2008). Distracted: The Erosion of Attention and the Coming Dark Age. New York: Prometheus Books.

Johnston, W. A., \& Heinz, S. P. (1978). Flexibility and capacity demands of attention. Journal of Experimental Psychology: General, 107, 420-435.

Judd, T. (2013). Making sense of multitasking: Key behaviours. Computers and Education, 63, April 2013, 358-367.

Maclin, E. L., Mathewson, K. E., Low, K. A., Boot, W. R., Kramer, A. F., Fabiani, M., \& Gratton, G. (2011). Learning to multitask: Effects of video game practice on electrophysiological indices of attention and resource allocation. Psychophisiology, 48, 11731183.

Monsell, S. (2003). Task switching. Trends in Cognitive Sciences, 7(3), 134-140.

Moray, N. (1969). Attention: Selective processes in vision and hearing. London: Hutchinson.

Mózes, T., Magyaródi, T., Soltész, P., Nagy, H., \& Oláh, A. (2014). The ways to operationalize flow experience. In A. Oláh, \& H. Nagy (Eds.), Flow, Emotional Intelligence and Psychological Immunity (pp. 11-20). Budapest: Eötvös University Press.

Nijboer, M., Taatgen, N. A., Brands, A., Borst, J. P., \& van Rijn, H. (2013). Decision Making in Concurrent Multitasking: Do People Adapt to Task Interference? PLoS ONE $8 b(11), 1-12$

Oblinger, D. G., \& Oblinger, J. L. (2005). Is It Age or IT: First Steps Toward Understanding the Net Generation. In D. G. Oblinger, \& J. L. Oblinger (Eds.), Educating the Net Generation. EDUCAUSE e-Book. www.educause.edu/educatingthenetgen/, 2.1-2.20.

Paivio, A. (1986). Mental representations: A dual coding approach. Oxford: Oxford University Press. 
Pashler, H., Kang, S. H., \& Ip, R. Y. (2013). Does Multitasking Impair Studying? Depends on Timing. Applied Cognitive Psychology, 27, 593-595.

Rosen, L. D., Lim, A. F., Carrier, M., \& Cheever, N. A. (2011). An Empirical Examination of the Educational Impact of Text Message-Induced Task Switching in the Classroom: Educational Implications and Strategies to Enhance Learning. Psicología Educativa, 17(2), 163-177.

Sanbonmatsu, D. M., Strayer, D. L., Medeiros-Ward, N., \& Watson, J. M. (2013). Who Multi-Tasks and Why? Multi-Tasking Ability, Perceived Multi-Tasking Ability, Impulsivity, and Sensation Seeking. PLoS ONE, 8(1), e54402.

Sanjram, P. K., \& Khan, A. (2011). Attention, polychronicity, and expertise in prospective memory performance: Programmers' vulnerability to habit intrusion error in multitasking. International Journal of Human-Computer Studies, June 2011, 428-439.

Small, G., \& Vorgan, G. (2011). Your brain is evolving right now. In M. Bauerlein (Ed.), The digital divide: arguments for and against Facebook, Google, texting, and the age of social networking (pp. 76-96). New York: Jeremy P. Tarcher/Penguin.

Spelke, E. S., Hirst, W. C., \& Neisser, U. (1976). Skills of divided attention. Cognition, 4, 215-230.

Tran, P., Carrillo, R., \& Subrahmanyam, K. (2013). Effects of online multitasking on reading comprehension of expository text. Cyberpsychology: Journal of Psychosocial Research on Cyberspace, 7(3), 2-20.

Treisman, A. M. (1964).Verbal cues, language, and meaning in selective attention. American Journal of Psychology, 77, 206-219.

Treisman, A., \& Davies, A. (1973). Divided attention to ear and eye. In S. Kornblum (Ed.), Attention and Performance IV (pp. 101-117). London: Academic Press.

Voorveld, H. A. M., \& van der Goot, M. (2013). Age Differences in Media Multitasking: A Diary Study. Journal of Broadcasting and Electronic Media, 57(3), 392-408.

Wieth, M. B., \& Burns, B. D. (2014). Rewarding Multitasking: Negative Effects of an Incentive on Problem Solving under Divided Attention. Journal of Problem Solving, 7, 6072.

\title{
THE EFFECT OF MULTITASKING ON TASK PERFORMANCE AND TIME MANAGEMENT: A PILOT STUDY OF METHODOLOGY
}

\author{
KVASZINGERNÉ PRANTNER, CSILLA - SOLTÉSZ, PÉTER - FARAGÓ, BOGLÁRKA - \\ PLÉH, CSABA - SOLTÉSZ-VÁRHELYI, KLÁRA
}

Background and goals: A main feature of the use of modern information- and communication technology (ICT) devices is the opportunity for multitasking that is dealing with several information sources running simultaneously. This means in the context of learning, that with minimal behavioral investment, ICT devices ease more rewarding attentional processes than our learning goals. Our research goal is modelling learning in ICT environment in lab circumstances, hereby examining the impact of multitasking on task performance. 
Methods: The main task was the Flanker test, which is the most common attentional and inhibition task. At the same time, the main task's solution was distracted by some (blinkering or another sort of) disturbing signals. These signals let people turning from the main task to the distractive stimuli such as fun games and limitless time spending with them. Subjects were 91 students from Eszterházy Károly College. Our goal was measuring the correlation between performance in the main task and length and number of relaxation with distractors.

Results: There weren't any relationships between the reaction time and number and length of relaxation. There was a strong negative correlation between the length of relaxation and performance, but there was no relationship between the number of pauses and performance. Promptly after the pause, the average reaction time increased. The more task the people do lead better results in proportion.

Conclusion: Our results support the pessimist multitasking metahypothesis. People with more pauses overrate the relaxation's impact on their performance, while actually there is more pause attached deterioration in performance. However, when people can control the length of relaxation, so the distracted stimuli don't take attention from the main task in the long run, these short relaxations have positive impact on performance.

Key words: ICT devices, multitasking, learning, attention, self-regulation 